\title{
NEW STRATEGIES FOR TREATMENT AND REUSE OF SPENT SULFIDIC CAUSTIC STREAM FROM PETROLEUM INDUSTRY
}

\author{
Jéssica Frontino Paulino e Júlio Carlos Afonso* \\ Departamento de Química Analítica, Instituto de Química, Universidade Federal do Rio de Janeiro, Av. Athos da Silveira Ramos, \\ 149, Bl. A, 21941-909 Rio de Janeiro - RJ, Brasil
}

Recebido em 19/8/11; aceito em 7/2/12; publicado na web em 15/6/12

\begin{abstract}
This work examines traditional and new routes for removal of $\mathrm{H}_{2} \mathrm{~S}$ and other sulfur compounds from spent sufidic caustic (SSC). $\mathrm{SH}^{-}$ (hydrogenosulfide) and $\mathrm{S}^{2-}$ (sulfide) ions were quantitatively oxidized at $25^{\circ} \mathrm{C}$ using $\mathrm{H}_{2} \mathrm{O}_{2}, \mathrm{NaOCl}$ or a spent sulfochromic mixture. $\mathrm{SH} / \mathrm{S}^{2-}$ ions were also removed via reaction with freshly prepared iron or manganese hydroxides, or after passing the SSC through strong basic anion exchange resins $\left(\mathrm{OH}^{-}\right.$form). The treated caustic solution, as well as iron/manganese hydroxides, removed $\mathrm{H}_{2} \mathrm{~S}$ from diesel samples at $25^{\circ} \mathrm{C}$. SSC treatment via strong basic anion-exchange resins produced the treated caustic solution with the highest free alkalinity.
\end{abstract}

Keywords: spent sulfidic caustic; soda reuse; sulfur removal.

\section{INTRODUCTION}

The effluents generated in petroleum refineries vary widely in terms of quantity and quality. This is determined by the type of feedstock processed, the existing units in the refinery and operational conditions. ${ }^{1}$ Some of these effluents must be treated individually because mixing with other waste streams makes their treatment more difficult. ${ }^{1,2}$ One such effluents is derived from the liquid-liquid contact of aqueous sodium hydroxide with a large variety of hydrocarbon streams. ${ }^{3}$ The objective is to remove hydrogen sulfide and other sulfur compounds such as thiols from these streams. This treatment is effective and low cost. ${ }^{4-6} \mathrm{H}_{2} \mathrm{~S}$ and other sulfur compounds lead to corrosion of concrete and metallic structures (due to their acidity), which poses difficulties in oil storage, use and handling. ${ }^{4}$ These substances also have a negative impacts on wastewater treatment. ${ }^{4,7,8}$ Their toxicity and malodorous properties deteriorate finished products, ${ }^{4,5}$ and must be treated for environmental protection. ${ }^{6,9,10}$ Once most $\mathrm{NaOH}$ has reacted with sulfur compounds, the solution is known as spent sulfidic caustic (SSC). ${ }^{11}$

SSC has high pH (usually above 13), dark color, foul odor and is highly toxic. It contains several contaminants such as sulfides, thiosulfates, thiols, phenols, naphtenic acids and emulsified hydrocarbons. ${ }^{8,12}$ Its composition is highly dependent on the type of refinery streams that have been treated..$^{13}$

Sodium hydroxide reacts with hydrogen sulfide as follows: ${ }^{14}$

$$
\mathrm{H}_{2} \mathrm{~S}+\mathrm{NaOH} \rightarrow \mathrm{NaSH}+\mathrm{H}_{2} \mathrm{O}
$$

SSC is classified by the RCRA (US Resource Conservation and Recovery Act) as hazardous waste. ${ }^{15}$ The odor and reactive (corrosive) nature of SSC does not allow direct biological treatment, even after neutralization and dilution. ${ }^{16}$ Direct neutralization of SSC releases $\mathrm{H}_{2} \mathrm{~S}$. SSC is also a powerful reducing agent. $\mathrm{SH}^{-}$(hydrogenosulfide) ions have a high oxygen demand $\left(2 \mathrm{~mol} \mathrm{O}_{2}\right.$ per mol HS $),{ }^{16}$ resulting in depletion of dissolved oxygen. Therefore, it is necessary to perform pre-treatment in order to reduce its impact on effluent treatment units. ${ }^{10,17}$

The most common methods used to remove sulfur compounds

*e-mail: julio@iq.ufrj.br from SSC are chemical oxidation, air stripping, wet air oxidation and precipitation. ${ }^{13,18-21}$ Wet air oxidation is conducted under high temperature and pressure. ${ }^{13,17} \mathrm{SH}^{-}$ions are converted into sulfate $\left(\mathrm{SO}_{4}{ }^{2-}\right)$ species. The treated SSC is mixed with a strong acid (usually sulfuric acid) so as to adjust $\mathrm{pH}$ close to $7 \cdot{ }^{13,15}$ In the chemical oxidation method, the most cited oxidants are hydrogen peroxide, sodium hypochlorite, potassium permanganate, chlorine and ferrate(VI) ions. ${ }^{22}$ Considerable safety measures must be taken in these processes. ${ }^{13}$ $\mathrm{SH} / \mathrm{S}^{2-}$ ions may be removed via precipitation with transition metals present in wastewaters, particularly under anaerobic conditions. ${ }^{21}$ The most employed metal by far is iron. ${ }^{2}$ It is cheap and presents low environmental impact. ${ }^{2,12,22}$ Iron-sulfur interaction has been the subject of extensive investigation. ${ }^{12,22,23}$ Other metals are scarcely cited in these studies. Fe(II) ions are precipitated as FeS and the yield is quantitative provided the $\mathrm{pH}$ is above 2-3 (otherwise FeS dissolves, releasing $\mathrm{H}_{2} \mathrm{~S}$ ). $\mathrm{Fe}(\mathrm{III})$ ions are reduced by $\mathrm{SH}^{-}$to $\mathrm{Fe}(\mathrm{II})$, this latter being precipitated as FeS together with elemental sulfur., ${ }^{2}$ Sulfur removal by redox methods is effective but can produce large amounts of chemical sludge.

Biological methods for $\mathrm{H}_{2} \mathrm{~S}$ (and other sulfur compounds) removal from effluents have received much attention since they may be more efficient and economical than traditional physicochemical methods, provided adequate operational conditions are employed. ${ }^{11,24}$ These methods have be performed on-site in many refineries. ${ }^{13} \mathrm{SH}^{-}$ions are preferably oxidized to sulfate species. This conversion is thermodynamically more favorable than the conversion $\mathrm{SH}^{-}$-elemental sulfur or thiosulfate. ${ }^{9,21,24}$ However there are situations where destruction of toxic pollutants is only possible by non-biological methods. ${ }^{2}$

Increasingly stringent environmental laws have stimulated research into new waste management strategies. New treatments are focused on the reuse of water and chemicals. ${ }^{1,13,15}$ In this regard, SSC can be handled in two ways: by reuse of treated SSC or replacement of the caustic solution by a solid base. Cutting down on water consumption reduces the cost of treatment and generation of final wastes. Other possibilities include the use of activated carbon for $\mathrm{H}_{2} \mathrm{~S}$ removal from liquid hydrocarbon streams ${ }^{4}$ and the use of membrane technology for $\mathrm{NaOH}$ recovery. ${ }^{12}$

The objective of this work was to evaluate the effectiveness of conventional and new oxidation routes for processing SSC. In a second step, new procedures for removal of sulfur compounds were 
tested but allowing the reuse of the treated caustic solution. This solution was employed to treat a hydrocarbon stream containing dissolved hydrogen sulfide.

\section{EXPERIMENTAL}

\section{Raw materials}

SSC from treatment of diesel fractions after desulfurization in a hydrotreater unit of a Brazilian refinery was used in this study. The main properties of the SSC are given in Table 1. The data presented fall within the range of values found in the literature for composition of SSC. ${ }^{12}$ Oils and greases were removed prior to the experiments using a phase separator drum. X-ray fluorescence showed the only metal present in detectable amounts was sodium.

Table 1. Characteristics of the SSC employed in this work

\begin{tabular}{cc}
\hline Color & dark brown-yellowish \\
Free alkalinity & $1.7 \mathrm{~mol} \mathrm{~L}^{-1}$ \\
$\mathrm{SH}^{-}$concentration & $0.7 \mathrm{~mol} \mathrm{~L}^{-1}\left(23 \mathrm{~g} \mathrm{~L}^{-1}\right.$ as S $)$ \\
Oils and greases & $1 \% \mathrm{vol}$. \\
$\mathrm{COD}$ & $27.8 \mathrm{~g} \mathrm{~L}^{-1}$ \\
\hline
\end{tabular}

Diesel samples containing $953 \mathrm{mg} \mathrm{L}^{-1} \mathrm{H}_{2} \mathrm{~S}$ were also used in this study. These samples were derived from the hydrotreater unit mentioned above.

\section{Treatment of SSC with oxidizing agents}

The oxidizing agents employed were: hydrogen peroxide (30 wt \%), sodium hypochlorite (5 wt $\%$ ) and a spent sulfochromic mixture (free acidity $8 \mathrm{~mol} \mathrm{~L}^{-1},[\mathrm{Cr}(\mathrm{III})]=0.8 \mathrm{~mol} \mathrm{~L}^{-1},[\mathrm{Cr}(\mathrm{VI})]=$ $\left.1.7 \mathrm{~mol} \mathrm{~L}^{-1}\right)$. All experiments were run at $25^{\circ} \mathrm{C}$ under magnetic stirring $(200 \mathrm{rpm})$ in $250 \mathrm{~mL}$ beakers. In the case of hydrogen peroxide and sodium hypochlorite, $50 \mathrm{~mL}$ of SSC were employed. Addition of the oxidizing solution was performed in $5 \mathrm{~mL}$ portions until full consumption of $\mathrm{SH}^{-}$ions. When the spent sulfochromic mixture was employed, 2-3 $\mathrm{mL}$ were added to $50 \mathrm{~mL}$ of SSC until disparition of $\mathrm{SH}^{-}$ions. These treatments were monitored by adding some drops of the treated SSC to $0.1 \mathrm{~mol} \mathrm{~L}^{-1}$ lead acetate in a filter paper. The presence of a black-brown precipitate $(\mathrm{PbS})$ indicates the presence of $\mathrm{SH}^{-}$ions in the SSC (detection limit $\left.1 \mathrm{mg} \mathrm{L}^{-1}\right){ }^{14,25}$ Reproducibility was found to be in the order of $\pm 3 \%$, by repeating the experiments in triplicate. After the oxidation procedure, the effluent was neutralized with $3 \mathrm{~mol} \mathrm{~L}^{-1}$ sulfuric acid until $\mathrm{pH} 7$.

\section{Removal of sulfur via precipitating agents}

The SSC was treated with freshly prepared iron or manganese hydroxides, prepared via the reaction of $0.2 \mathrm{~mol} \mathrm{~L}^{-1} \mathrm{FeCl}_{3}, 0.2 \mathrm{~mol} \mathrm{~L}^{-1}$ $\mathrm{MnCl}_{2}$ or $0.2 \mathrm{~mol} \mathrm{~L}^{-1} \mathrm{FeSO}_{4}$ with $6 \mathrm{~mol} \mathrm{~L}^{-1} \mathrm{NaOH}$ :

$$
\begin{aligned}
\mathrm{FeCl}_{3}+3 \mathrm{NaOH} & \rightarrow \mathrm{Fe}(\mathrm{OH})_{3} \downarrow+3 \mathrm{NaCl} \\
\mathrm{FeSO}_{4}+2 \mathrm{NaOH} & \rightarrow \mathrm{Fe}(\mathrm{OH})_{2} \downarrow+\mathrm{Na}_{2} \mathrm{SO}_{4} \\
\mathrm{MnCl}_{2}+2 \mathrm{NaOH} & \rightarrow \mathrm{Mn}(\mathrm{OH})_{2} \downarrow+2 \mathrm{NaCl}
\end{aligned}
$$

$\mathrm{Mn}(\mathrm{II})$ was readily oxidized to $\mathrm{Mn}(\mathrm{IV})$ by adding some drops of $\mathrm{H}_{2} \mathrm{O}_{2}(30 \mathrm{wt} \%)$ :

$$
\mathrm{Mn}(\mathrm{OH})_{2}+\mathrm{H}_{2} \mathrm{O}_{2} \rightarrow \mathrm{MnO}(\mathrm{OH})_{2} \downarrow+\mathrm{H}_{2} \mathrm{O}
$$

The precipitates were filtered in a filter paper under vacuum. They were not washed. The SSC was passed in $2 \mathrm{~mL}$ portions (1.5 $\mathrm{mL} \mathrm{min}^{-1}$ ) through these precipitates (kept in the filter paper) until the lead acetate test produced a positive result. This test is more reliable than using visual control of the color change of the precipitate, from orange-brown $\left(\mathrm{Fe}(\mathrm{OH})_{3}\right)$ or green $\left(\mathrm{Fe}(\mathrm{OH})_{2}\right)$ to black $(\mathrm{FeS})$, or from dark-brown $\left(\mathrm{MnO}(\mathrm{OH})_{2}\right)$ to pink-yellow $(\mathrm{MnS}+\mathrm{S})$. Like iron, manganese presents a variable oxidation state $(+2$ to +4$)$. Reproducibility was found to be in the order of $\pm 5 \%$, by repeating the experiments in triplicate.

\section{Removal of sulfur via ion-exchange resins}

Two strong basic anion exchange resins (type-I) were employed for sulfide adsorption from the SSC: Amberlite IRA 420 (Carlo Erba), Dowex 1 (Dow Chemicals). The main properties of these resins are shown in Table 2. According to the literature, no previous study on

\begin{tabular}{|c|c|c|}
\hline Description & Amberlite IRA 420 & Dowex 1 \\
\hline Matrix & Styrene-divinylbenzene & Styrene-divinylbenzene \\
\hline Functional group & Quaternary ammonium & Quaternary ammonium \\
\hline Structure & Macroporous & Macroporous \\
\hline Ionic form & $\mathrm{Cl}^{-}$ & $\mathrm{Cl}^{-}$ \\
\hline Apparent density & $650 \mathrm{~g} \mathrm{~L}^{-1}$ & $705 \mathrm{~g} \mathrm{~L}^{-1}$ \\
\hline Exchange capacity & $1.3 \mathrm{eq} \mathrm{L}^{-1}$ & $1.4 \mathrm{eq} \mathrm{L}^{-1}$ \\
\hline Grain size & $0.125-0.177 \mathrm{~mm}$ & $0.30-1.20 \mathrm{~mm}$ \\
\hline Operating $\mathrm{pH}$ range & $0-14$ & $0-14$ \\
\hline $\begin{array}{l}\text { Moisture retention } \\
\text { capacity }(\%)\end{array}$ & $50-55$ & $43-48$ \\
\hline
\end{tabular}
the processing of SSC samples by ion-exchange techniques has been published.

Table 2. Anion exchange resins characteristics

The dynamic method was applied in this study. Glass columns (diameter $d=10 \mathrm{~mm}$ ) were packed with a slurry of the resin until the settled resin bed attained the established height $(\mathrm{L}=100 \mathrm{~cm})$. Therefore, $\mathrm{L} / d$ ratio was 100 in all experiments. The resins were previously equilibrated with $1 \mathrm{~mol} \mathrm{~L}^{-1} \mathrm{NaOH}$ for $2 \mathrm{~h}$. The SSC was passed through a calibrated rotameter $\left(1.5 \mathrm{~mL} \mathrm{~min}^{-1}\right)$ before entering the column, at room temperature $\left(\sim 25^{\circ} \mathrm{C}\right)$. The eluate was collected for sulfur analysis. The capacity of the resins to retain sulfur was estimated from a breakthrough study. For this purpose, the SSC and a standard $\mathrm{Na}_{2} \mathrm{~S}$ solution $\left(1 \mathrm{~g} \mathrm{~L}^{-1}\right.$, free alkalinity $\left.1.0 \mathrm{~mol} \mathrm{~L}^{-1}\right)$ were employed. Flow rate was $1.5 \mathrm{~mL} \mathrm{~min}^{-1}$ and the experiments were performed at room temperature $\left(\sim 25^{\circ} \mathrm{C}\right)$.

Sulfur desorption was tested using freshly prepared $\mathrm{H}_{2} \mathrm{O}_{2}$ (1-6 $\mathrm{mol} \mathrm{L}^{-1}$ in $\mathrm{NaOH} 1 \mathrm{~mol} \mathrm{~L}^{-1}$ ). Flow rate was fixed at $1.0 \mathrm{~mL} \mathrm{~min}{ }^{-1}$ and experiments were run at $25^{\circ} \mathrm{C}$. The eluate was collected for sulfur analysis. All experiments in this section were run in triplicate and data obtained were within $\pm 5 \%$.

\section{Removal of $\mathrm{H}_{2} \mathrm{~S}$ from diesel fractions}

The SSC treated with iron/manganese hydroxides or via ion-exchange resins was employed to treat diesel samples containing sulfur compounds. Free alkalinity was kept as such.

Liquid-liquid extractions were performed at $25{ }^{\circ} \mathrm{C}$ using an aqueous/organic phase ratio (A/O) equal to 1 (10 mL of caustic solution $+10 \mathrm{~mL}$ diesel). The contact time was $3 \mathrm{~min}$. After removal of the treated diesel, $10 \mathrm{~mL}$ of a new sample was treated with the 
same caustic solution. The presence or absence of $\mathrm{H}_{2} \mathrm{~S}$ was assessed by placing drops of treated diesel in a filter paper containing lead acetate. Reproducibility was found to be in the order of $\pm 4 \%$, by repeating the experiments in triplicate.

The possibility of removal of sulfur compounds directly from diesel using $\mathrm{MnO}(\mathrm{OH})_{2}, \mathrm{Fe}(\mathrm{OH})_{3}$ or $\mathrm{Fe}(\mathrm{OH})_{2}$, prepared as described earlier, was also investigated. After filtration of the hydroxide, approximately $100 \mathrm{mg}$ were mixed into $100 \mathrm{~mL}$ of diesel. This mixture was stirred $(200 \mathrm{rpm})$ at $25^{\circ} \mathrm{C}$ for $3 \mathrm{~min}$. Diesel was easily separated from the solid by decantation or centrifuging. The recovered solid was introduced to $100 \mathrm{~mL}$ of a new sample. This cycle was stopped when the lead acetate test gave a positive result in the treated diesel. Reproducibility was found to be in the order of $\pm 5 \%$, by repeating the experiments four times.

\section{Analytical methods}

Chemical oxygen demand (COD) was determined by the method described elsewhere in the literature. ${ }^{26}$ Free alkalinity was measured by the potentiometric method using a glass electrode and $0.805 \mathrm{~mol}$ $\mathrm{L}^{-1} \mathrm{HCl} .{ }^{27}$ Free acidity was measured in a similar manner with 0.205 mol L-1 KOH. $\mathrm{pH}$ was measured with a glass electrode. ${ }^{27}$ Crystalline phases in the iron/manganese hydroxide samples were identified by $\mathrm{X}$-ray diffraction analysis (Bruker-AXS D5005) and the continuous scanning method at $35 \mathrm{kV}$ and $40 \mathrm{~mA}$, using $\mathrm{Co} \mathrm{K} \alpha$ as the radiation source. Sulfide ions were determined by an ion-selective electrode (Orion 9616 BNWP).

\section{RESULTS AND DISCUSSION}

\section{Oxidative treatment}

$20 \mathrm{~mL}$ of $\mathrm{H}_{2} \mathrm{O}_{2}$ or $125 \mathrm{~mL}$ of $\mathrm{NaOCl}$ were required to treat $50 \mathrm{~mL}$ of SSC. The reactions involving these oxidants are: ${ }^{14,25}$

$$
\begin{gathered}
\mathrm{HS}^{-}+4 \mathrm{H}_{2} \mathrm{O}_{2} \rightarrow 4 \mathrm{H}_{2} \mathrm{O}+\mathrm{SO}_{4}{ }^{2-}+\mathrm{H}^{+} \\
\mathrm{HS}^{-}+4 \mathrm{NaOCl} \rightarrow 4 \mathrm{NaCl}+\mathrm{SO}_{4}{ }^{2-}+\mathrm{H}^{+}
\end{gathered}
$$

No elemental sulfur was formed in these oxidative treatments. ${ }^{9,21}$ COD was reduced by more than $99 \%$. The oxidation of organic matter explains why consumption of $\mathrm{H}_{2} \mathrm{O}_{2}$ and $\mathrm{NaOCl}$ were higher $(\approx 20 \%)$ than the stoichiometric amount required to oxidize all SH ions (reactions 6 and 7).

$\mathrm{H}_{2} \mathrm{O}_{2}$ must be added slowly under stirring because the reaction is very exothermic. $\mathrm{NaOCl}$ does not present this problem, but the volume of treated waste is higher because of its low concentration. After neutralization with sulfuric acid, no turbidity and precipitation were observed.

The use of SSC to treat spent sulfochromic mixture was aimed at employing it as a reactant to treat other wastes. $\mathrm{SH}^{-}$removal via mixture of appropriate wastes reduces consumption of water and chemicals. These wastes must contain reactive components such as oxidant - reducing and acidic - alkaline species. The reaction between $\mathrm{SH}^{-}$and $\mathrm{Cr}(\mathrm{VI})$ may be expressed as:

$$
29 \mathrm{H}^{+}+3 \mathrm{SH}^{-}+4 \mathrm{Cr}_{2} \mathrm{O}_{7}^{2-} \rightarrow 3 \mathrm{SO}_{4}^{2-}+8 \mathrm{Cr}^{3+}+16 \mathrm{H}_{2} \mathrm{O}
$$

It occurs simultaneously to neutralization of both wastes:

$$
\mathrm{H}^{+}+\mathrm{OH}^{-} \rightarrow \mathrm{H}_{2} \mathrm{O}
$$

$50 \mathrm{~mL}$ of spent sulfochromic mixture treated $40 \mathrm{~mL}$ of SSC. The amounts of $\mathrm{Cr}(\mathrm{VI})$ and $\mathrm{SH}^{-}$mixed indicate that the amount of the latter was not sufficient to reduce all $\mathrm{Cr}$ (VI) (no elemental sulfur was formed). As in the other oxidative treatments, organic matter was also oxidized by $\mathrm{Cr}(\mathrm{VI})$. COD was reduced by more than $99 \%$. This explains the colorless aspect of treated SSC (as seen in Figure 1). Free acidity was drastically reduced from 8 to about $0.5 \mathrm{~mol} \mathrm{~L}^{-1}$ ( $\approx 6 \%$ of the initial value). This is basically due to the oxidation of $\mathrm{SH}^{-}$ions (reaction 8) and the organic matter. Addition of $6 \mathrm{~mol} \mathrm{~L}^{-1}$ $\mathrm{NaOH}$ until pH 7-8 formed a green precipitate, $\mathrm{Cr}(\mathrm{OH})_{3}$, that was subsequently filtered. The original features of the SSC - dark color, foul odor and high toxicity - are no longer observed after treatment (Figure 1) with these oxidants. The final treated effluent meets the requirements for disposal of treated aqueous effluents according to the Directory 357 from the Brazilian National Environmental Council. ${ }^{28}$

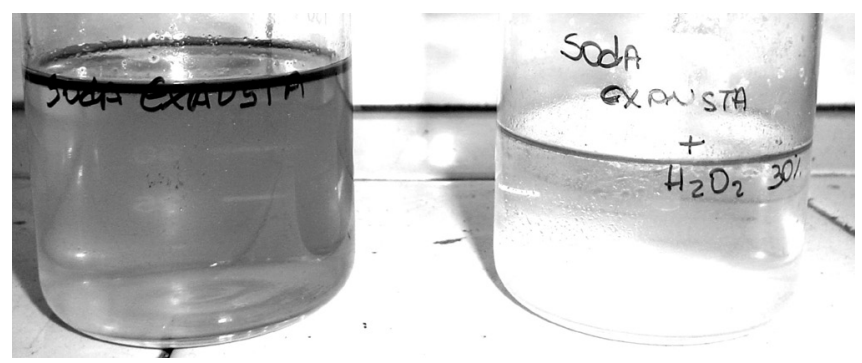

Figure 1. SSC before (left) and after treatment (right) with $\mathrm{H}_{2} \mathrm{O}_{2}$

When two wastes are treated together, the order of addition depends on the relative amounts of reactive species. In the present case, the mixture of both wastes cannot release hydrogen sulfide. If the spent sulfochromic mixture was added to the SSC, the free alkalinity of the latter would be rapidly consumed before oxidation of all $\mathrm{SH}^{-}$ions, favoring $\mathrm{H}_{2} \mathrm{~S}$ release.

The disadvantage of treatments with oxidizing agents is the generation of an end waste containing high amounts of $\mathrm{Na}_{2} \mathrm{SO}_{4}$. Reduction or even suppression of this effluent requires removal of $\mathrm{SH}^{-}$ions by precipitation.

\section{Sulfur removal via precipitation of insoluble sulfides}

This treatment is based on the following reactions:

$$
\begin{gathered}
2 \mathrm{Fe}(\mathrm{OH})_{3}+3 \mathrm{NaSH} \rightarrow 2 \mathrm{FeS} \downarrow+\mathrm{S} \downarrow+3 \mathrm{NaOH}+3 \mathrm{H}_{2} \mathrm{O} \\
\mathrm{Fe}(\mathrm{OH})_{2}+\mathrm{NaSH} \rightarrow \mathrm{FeS} \downarrow+\mathrm{NaOH}+\mathrm{H}_{2} \mathrm{O} \\
\mathrm{MnO}(\mathrm{OH})_{2}+\mathrm{NaSH} \rightarrow \mathrm{Mn}(\mathrm{OH})_{2} \downarrow+\mathrm{S} \downarrow+\mathrm{NaOH} \\
\mathrm{Mn}(\mathrm{OH})_{2}+\mathrm{NaSH} \rightarrow \mathrm{MnS} \downarrow+\mathrm{NaOH}+\mathrm{H}_{2} \mathrm{O}
\end{gathered}
$$

$\mathrm{Fe}(\mathrm{III})$ is reduced to $\mathrm{Fe}(\mathrm{II})$, precipitating as FeS. In a similar manner, $\mathrm{Mn}(\mathrm{IV})$ is reduced to $\mathrm{Mn}$ (II). MnS is its final product. According to reactions 10 and $11, \mathrm{Fe}$ (III) can react with $50 \%$ more $\mathrm{SH}^{-}$ions than $\mathrm{Fe}(\mathrm{II})$. In fact, experimental data indicate that $\mathrm{Fe}(\mathrm{OH})_{3}$ treated $45 \%$ more SSC than $\mathrm{Fe}(\mathrm{OH})_{2}$. However, $\mathrm{Mn}(\mathrm{IV})$ was more effective than $\mathrm{Fe}(\mathrm{III}) . \mathrm{MnO}(\mathrm{OH})_{2}$ treated $30 \%$ more SSC than $\mathrm{Fe}(\mathrm{OH})_{3}$. This is due to the higher oxidation state of manganese.

Based on reactions 10 to 13 , generation of $\mathrm{NaOH}$ as one of the products would increase or, at least, keep free alkalinity of the treated SSC. However, although $\mathrm{SH}^{-}$ions were quantitatively removed, free alkalinity slightly decreased (Table 3), especially when SSC was treated with $\mathrm{Fe}(\mathrm{OH})_{3}$.

It is important to mention that the hydroxides were not washed after precipitation. In separated experiments, after the first washing, water presented $\mathrm{pH}$ around 3 and $\mathrm{Cl}^{-}\left(\mathrm{Fe}^{3+}\right.$ ions) or $\mathrm{pH} 4$ and $\mathrm{SO}_{4}^{2-}$ ( $\mathrm{Fe}^{2+}$ ions). $\mathrm{Fe}^{3+}$ ions are more subject to hydrolysis than the $\mathrm{Fe}^{2+}$ ions. Perhaps these facts explain the higher decrease in free alkalinity of 
Table 3. Free alkalinity of SSC before and after treatment with $\mathrm{Fe} / \mathrm{Mn}$ hydroxides

\begin{tabular}{cl}
\hline SSC & Free $\left[\mathrm{OH}^{-}\right]$ \\
\hline Original & $1.7 \mathrm{~mol} \mathrm{~L}^{-1}$ \\
After treatment with $\mathrm{Fe}(\mathrm{OH})_{2}$ & $1.5 \mathrm{~mol} \mathrm{~L}^{-1}$ \\
After treatment with $\mathrm{Fe}(\mathrm{OH})_{3}$ & $1.3 \mathrm{~mol} \mathrm{~L}^{-1}$ \\
After treatment with $\mathrm{MnO}(\mathrm{OH})_{2}$ & $1.6 \mathrm{~mol} \mathrm{~L}^{-1}$ \\
\hline
\end{tabular}

SSC treated with $\mathrm{Fe}(\mathrm{OH})_{3}$. When iron hydroxides were washed until $\mathrm{pH}$ of washing waters $=7$ the solids lost virtually all ability to act as a sink for sulfur. X-ray diffraction data of the non-washed and washed solids are shown in Figures 2 and 3, respectively. Crude $\mathrm{Fe}(\mathrm{OH})_{3}$ is essentially an amorphous solid. After washing, some crystalline structures were formed. Almost all peaks represent goethite $(\alpha-\mathrm{FeOOH})$. This result is different from literature data, ${ }^{22}$ where washing crude $\mathrm{Fe}(\mathrm{OH})_{3}$ converted it to lepidocrocite $(\gamma-\mathrm{FeOOH})$, which is much less reactive than the amorphous form for $\mathrm{H}_{2} \mathrm{~S}$ removal. It appears that crystallization of the initial amorphous solid suppressed its ability to react with $\mathrm{NaSH}$.

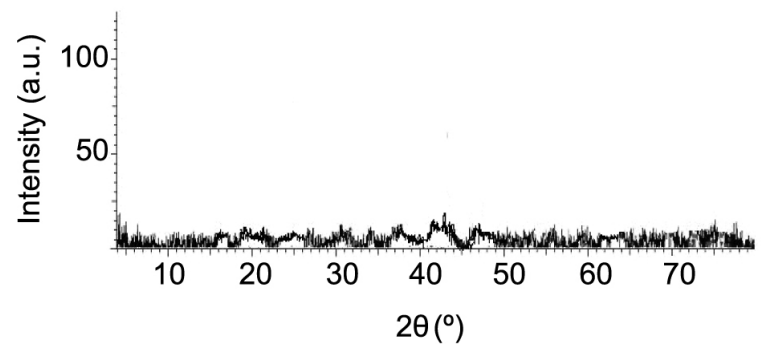

Figure 2. X-ray diffractogram of non-washed $\mathrm{Fe}(\mathrm{OH})_{3}$. It is essentially an amorphous solid

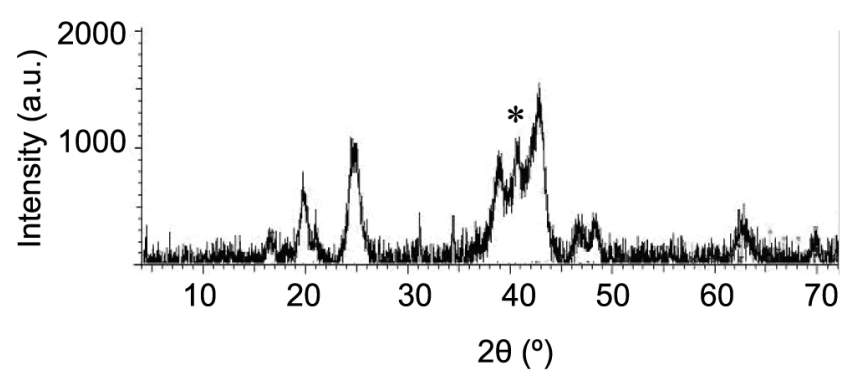

Figure 3. $\mathrm{X}$-ray diffractogram of the washed $\mathrm{Fe}(\mathrm{OH})_{3}$. The peak represents goethite $(\alpha \mathrm{FeOOH})$. The peak assigned with an * represent iron oxide $\left(\mathrm{Fe}_{2} \mathrm{O}_{3}\right)$

After the first washing of $\mathrm{MnO}(\mathrm{OH})_{2}$, the $\mathrm{pH}$ was around 5. $\mathrm{Cl}^{-}$ions were present in small amounts and no detectable Mn was observed. Washing until $\mathrm{pH} 7$ decreased $\mathrm{SH}^{-}$uptake by $70 \%$. XRD data indicated the solid was amorphous both before and after washing.

Another possible explanation is the absorption of $\mathrm{CO}_{2}$ during handling of SSC. According to reaction 14, some free alkalinity is consumed:

$$
\mathrm{CO}_{2}+\mathrm{OH}^{-} \rightarrow \mathrm{HCO}_{3}^{-}
$$

After acidifying a sample of treated SSC with $2 \mathrm{~mol} \mathrm{~L}^{-1} \mathrm{HCl}$, the gas was passed through $0.2 \mathrm{~mol} \mathrm{~L}^{-1} \mathrm{Ba}(\mathrm{OH})_{2}$, giving a white precipitate $\left(\mathrm{BaCO}_{3}\right)$. This result confirms the presence of hydrogenocarbonate ions in the treated SSC. ${ }^{14,25}$ However, from the amount of $\mathrm{BaCO}_{3}$ recovered and weighed, the estimated concentration of $\mathrm{HCO}_{3}^{-}$is relatively small, $0.05 \mathrm{~mol} \mathrm{~L}^{-1}$.

Treatments based on precipitation are of interest because they allow reuse of treated SSC. This strategy reduces waste generation and consumption of water and chemicals. ${ }^{29} \mathrm{SSC}$ treated in this way presents a yellowish aspect. Although sulfur compounds were removed, 10\% COD remained in the treated SSC. The solid produced, $\mathrm{FeS}$ or $\mathrm{MnS}(+\mathrm{S})$, may be oxidized by hydrogen peroxide or sodium hypochlorite at $25{ }^{\circ} \mathrm{C}$ in alkaline medium $\left(2 \mathrm{~mol} \mathrm{~L}^{-1} \mathrm{NaOH}\right)$, thus allowing recovery of iron or manganese hydroxides:

$$
\begin{aligned}
& 4 \mathrm{NaOH}+2 \mathrm{FeS} \downarrow+9 \mathrm{H}_{2} \mathrm{O}_{2} \rightarrow 8 \mathrm{H}_{2} \mathrm{O}+2 \mathrm{Na}_{2} \mathrm{SO}_{4}+2 \mathrm{Fe}(\mathrm{OH})_{3} \downarrow \\
& \mathrm{H}_{2} \mathrm{O}+4 \mathrm{NaOH}+2 \mathrm{FeS} \downarrow+9 \mathrm{NaOCl} \rightarrow 9 \mathrm{NaCl}_{2}+2 \mathrm{Na}_{2} \mathrm{SO}_{4} \\
& +2 \mathrm{Fe}(\mathrm{OH})_{3} \downarrow \\
& 2 \mathrm{NaOH}+\mathrm{MnS} \downarrow+5 \mathrm{H}_{2} \mathrm{O}_{2} \rightarrow 5 \mathrm{H}_{2} \mathrm{O}+\mathrm{Na}_{2} \mathrm{SO}_{4}+\mathrm{MnO}(\mathrm{OH})_{2} \downarrow \\
& 2 \mathrm{NaOH}+\mathrm{MnS} \downarrow+5 \mathrm{NaOCl} \rightarrow 5 \mathrm{NaCl}+\mathrm{Na}_{2} \mathrm{SO}_{4}+\mathrm{MnO}(\mathrm{OH})_{2} \downarrow
\end{aligned}
$$

Addition of the oxidant must be slow and under stirring (200 rpm) at $25^{\circ} \mathrm{C}$. The concentration of the oxidant must be low (reactions 15 to 18 are highly exothermic). Filtration was performed under vacuum. No attempt was made to separate $\mathrm{MnO}(\mathrm{OH})_{2}$ or $\mathrm{Fe}(\mathrm{OH})_{3}$ from elemental sulfur. The solids were used to treat diesel samples (see below).

\section{Sulfur removal via ion-exchange resins}

Figure 4 shows the breakthrough curves for sulfur present in the $\operatorname{SSC}\left(0,7 \mathrm{~mol} \mathrm{~L}^{-1} \mathrm{SH}^{-}\right)$and $1 \mathrm{~mol} \mathrm{~L}^{-1} \mathrm{Na}_{2} \mathrm{~S}$ (in $\left.1 \mathrm{~mol} \mathrm{~L}^{-1} \mathrm{NaOH}\right)$ on the resins. The behavior of the two resins and reference solution was very similar. From data presented in this figure, the average sulfur uptake was $22.5 \mathrm{~g} \mathrm{~L}^{-1}$ (Dowex 1) and $21.0 \mathrm{~g} \mathrm{~L}^{-1}$ (Amberlite IRA 420).

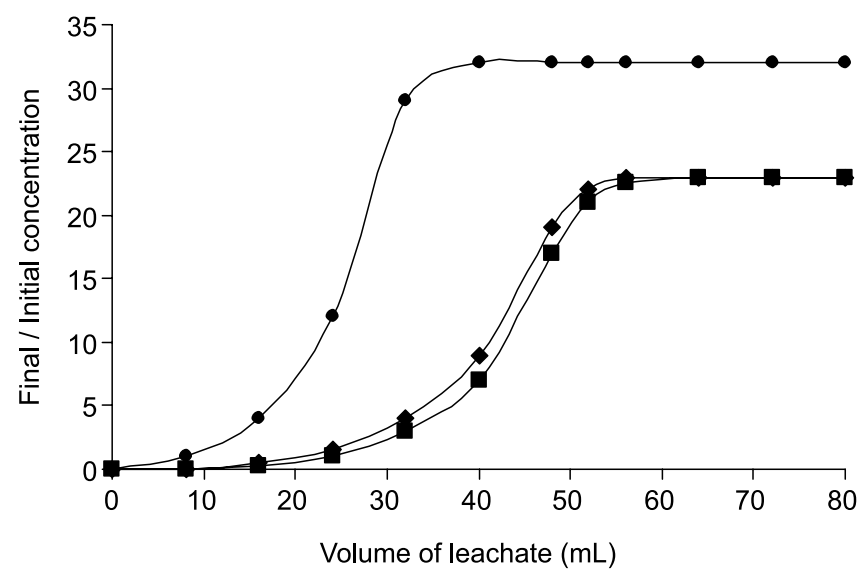

Figure 4. Breakthrough curves for sulfur (as $\left.S^{2-}\right)$ present in the SSC $(0.7 \mathrm{~mol}$ $\mathrm{L}^{-1} \mathrm{SH}^{-}$in $1.7 \mathrm{~mol} \mathrm{~L}^{-1} \mathrm{OH}^{-}$) or $1 \mathrm{~mol} \mathrm{~L}^{-1} \mathrm{Na}_{2} \mathrm{~S}$ (in $1 \mathrm{~mol} \mathrm{~L}^{-1} \mathrm{OH}^{-}$) on Amberlite IRA 420 and Dowex 1 resins

From the exchange capacity of these resins given in Table 2, these results indicate that sulfur is basically adsorbed as $\mathrm{S}^{2-}$ ions on both resins since experimental uptake was about half of their exchange capacity shown in Table 2 . The resin darkened somewhat and the eluate was almost colorless. Since under the $\mathrm{pH}$ of the SSC studied there is a mixture of $\mathrm{SH}^{-}$and $\mathrm{S}^{2-}$ ions,${ }^{30}$ the speciation of sulfur inside the resin phases is different from that in the SSC. The free alkalinity of the eluate (treated SSC) was higher $\left(2.0 \mathrm{~mol} \mathrm{~L}^{-1}\right)$ than the original value $\left(1.7 \mathrm{~mol} \mathrm{~L}^{-1}\right)$ for the SSC. This result may be explained by the following reactions:

$$
\begin{gathered}
2 \text { resin- } \mathrm{OH}+\mathrm{SH}^{-} \rightarrow(\text { resin- })_{2} \mathrm{~S}+\mathrm{H}_{2} \mathrm{O}+\mathrm{OH}^{-} \\
2 \text { resin- } \mathrm{OH}+\mathrm{S}^{2-} \rightarrow(\text { resin- })_{2} \mathrm{~S}+2 \mathrm{OH}^{-}
\end{gathered}
$$

The great advantage of SSC treatment via ion-exchange resins is the increase in free alkalinity, which reaches about the same level as 
the original caustic solution $\left(2 \mathrm{~mol} \mathrm{~L}^{-1}\right)$. When precipitation methods were employed, the free alkalinity of the treated caustic solutions was reduced as discussed earlier.

As shown in the literature, strong basic anion-exchange resins strongly retain $\mathrm{S}^{2-}$ ions, which are not displaced by $\mathrm{OH}^{-}$ions even in a highly alkaline medium. ${ }^{30,31}$ The adjustment of $\mathrm{pH}$ to lower values is not a good practice because $\mathrm{H}_{2} \mathrm{~S}$ is released when $\mathrm{pH}$ is below $9 .{ }^{30}$ Therefore, the alternative was to oxidize $\mathrm{S}^{2-}$ fixed to the resins. ${ }^{31}$

As expected, the increase of $\mathrm{H}_{2} \mathrm{O}_{2}$ concentration markedly decreased the amount of solution necessary to oxidize sorbed $\mathrm{S}^{2-}$ (Figure 5). However, since this oxidation is highly exothermic, the oxidant concentration must be low in order to avoid overheating of the resins. The best results were obtained when $\mathrm{H}_{2} \mathrm{O}_{2}$ alkaline solution was cold $\left(5-10{ }^{\circ} \mathrm{C}\right.$ ) and $\mathrm{H}_{2} \mathrm{O}_{2}$ concentration did not exceed $3 \mathrm{~mol} \mathrm{~L}^{-1}$. The eluate was colorless thus suggesting that the organic matter sorbed was also oxidized in this procedure. No elemental sulfur was formed under our experimental conditions:

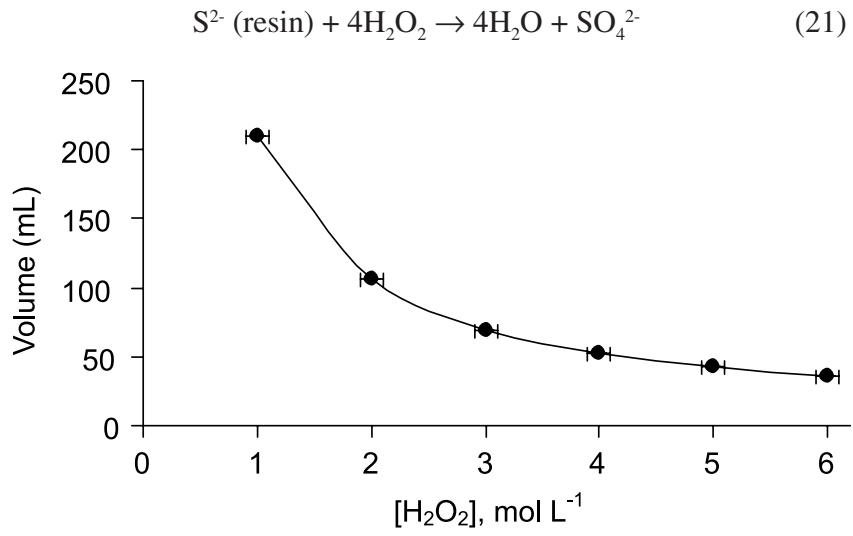

Figure 5. Influence of $\mathrm{H}_{2} \mathrm{O}_{2}$ concentration (in $1 \mathrm{~mol} \mathrm{~L} \mathrm{~L}^{-1} \mathrm{NaOH}$ ) on sulfur desorption via oxidation from Amberlite IRA 420

\section{Reuse of treated SSC}

Treatment of diesel samples containing $953 \mathrm{mg} \mathrm{L}^{-1} \mathrm{H}_{2} \mathrm{~S}$ with the four treated caustic solutions according to the experimental procedure described previously was performed under the same conditions described earlier. As expected, the amount of diesel treated increased with increasing free alkalinity (Table 4). The presence of residual organic matter and $\mathrm{HCO}_{3}{ }^{-}$ions apparently did not influence absorption of sulfur compounds. The amount of diesel treated is about $2 \%$ vol. higher than the theoretical amount (according to Equation 1), due to the loss of some $\mathrm{H}_{2} \mathrm{~S}$ during diesel handling.

Table 4. Volumes of diesel treated with $10 \mathrm{~mL}$ of several treated SSC

\begin{tabular}{cccc}
\hline \multirow{2}{*}{$\begin{array}{c}\text { Free alkalinity } \\
\left(\mathrm{mol} \mathrm{L}^{-1}\right)\end{array}$} & \multicolumn{2}{c}{ Diesel treated $(\mathrm{mL})$} & $\begin{array}{c}\text { Free alkalinity } \\
\text { after treatment } \\
\left(\mathrm{mol} \mathrm{L}^{-1}\right)\end{array}$ \\
\cline { 2 - 4 } & 700 & 715 & 1.6 \\
1.0 & 560 & 575 & 1.3 \\
1.5 & 525 & 535 & 1.1 \\
1.3 & 455 & 465 & 1.0 \\
\hline
\end{tabular}

\section{Direct removal of $\mathrm{H}_{2} \mathrm{~S}$ from diesel}

The goal was to avoid generation of wastewaters by employing a solid base, $\mathrm{MnO}(\mathrm{OH})_{2}$ or $\mathrm{Fe}(\mathrm{OH})_{3}$, freshly prepared and not washed, in contact with diesel. ${ }^{4,22,29}$ The reactions are:

$$
\begin{gathered}
2 \mathrm{Fe}(\mathrm{OH})_{3}+3 \mathrm{H}_{2} \mathrm{~S} \rightarrow 2 \mathrm{FeS} \downarrow+\mathrm{S} \downarrow+3 \mathrm{H}_{2} \mathrm{O} \\
\mathrm{MnO}(\mathrm{OH})_{2}+2 \mathrm{H}_{2} \mathrm{~S} \rightarrow \mathrm{MnS} \downarrow+\mathrm{S} \downarrow+3 \mathrm{H}_{2} \mathrm{O}
\end{gathered}
$$

These reactions were only feasible when the hydroxides were stirred $(200 \mathrm{rpm})$ with diesel. Percolation of the diesel through these solids, as in the case of treatment of SSC was not successful. The permeation rate of the organic liquid was extremely slow $\left(<0.2 \mathrm{~mL} \mathrm{~min}^{-1}\right)$.

$100 \mathrm{mg} \mathrm{Fe}(\mathrm{OH})_{3}$ treated $52 \mathrm{~mL}$ diesel (addition of $5 \mathrm{~mL}$ in portions). The theoretical volume was $50 \mathrm{~mL}$. $100 \mathrm{mg} \mathrm{MnO}(\mathrm{OH})_{2}$ treated $70 \mathrm{~mL}$ (theoretical volume $67 \mathrm{~mL}$ ). Once again, some $\mathrm{H}_{2} \mathrm{~S}$ was lost during handling. The solid was easily centrifuged or decanted (but the mixture must not be passed through a filter paper because filtration is too slow). $\mathrm{MnO}(\mathrm{OH})_{2}$ and $\mathrm{Fe}(\mathrm{OH})_{3}$ obtained after oxidation of $\mathrm{MnS}$ (reactions 15 and 16) or FeS (reactions 13 and 14) were $\sim 10 \%$ less reactive, probably due to the presence of sulfur as a non-reactive component.

\section{CONCLUSIONS}

It was possible to remove sulfur compounds from SSC via chemical oxidation with hydrogen peroxide, sodium hypochlorite or a spent sulfochromic mixture (containing $\mathrm{Cr}(\mathrm{VI})$ ), at $25^{\circ} \mathrm{C}$ under stirring (200 rpm). Besides sulfur compounds, the organic matter was almost fully eliminated, thus producing a colorless treated effluent. Spent acidic and or oxidizing effluents may be mixed with SSC provided addition of these effluents avoids release of toxic substances (such as $\mathrm{H}_{2} \mathrm{~S}$ ). This procedure avoids consumption of chemicals and water. However, SSC is destroyed in this way and must be neutralized before final disposal.

Removal of sulfur compounds from SSC was also performed via treatment with freshly prepared and non-washed manganese/iron hydroxides, at $25^{\circ} \mathrm{C}$, by percolating the SSC through the solid hydroxide. Treatment via percolation in anion-exchange resins was also a successful technique. The free alkalinity of treated SSC decreased in the order: anion-exchange resin $>\mathrm{Mn}$ (IV) $>\mathrm{Fe}$ (II) $>\mathrm{Fe}$ (III). The treated SSC absorbed $\mathrm{H}_{2} \mathrm{~S}$ from diesel samples. The greater the free alkalinity the higher the volume of diesel treated.

Diesel was successfully directly treated with iron/manganese hydroxides, under stirring at $25^{\circ} \mathrm{C}$, the solid being easily decanted or centrifuged, and reused until full conversion to $\mathrm{FeS} / \mathrm{MnS}(+\mathrm{S})$. These solids may be treated via oxidation in order to recover $\mathrm{MnO}(\mathrm{OH})_{2}$ or $\mathrm{Fe}(\mathrm{OH})_{3}$, but their reactivity was somewhat lower because of the presence of non-reactive matter (sulfur).

\section{ACKNOWLEDGEMENTS}

J. F. Paulino acknowledges Agência Nacional de Petróleo, Gás Natural e Biocombustíveis (ANP) for a fellowship. We are grateful to ANP for financial support. We thank PETROBRAS/CENPES/ PDAB-PP for supply of SSC and diesel samples containing dissolved hydrogen sulfide. We are grateful to R E. Santelli (IQ/UFRJ) for a critical reading of this paper.

\section{REFERENCES}

1. Bagajewicz, M.; Comput. Chem. Eng. 2000, 24, 2093.

2. Altas, L.; Büyükgüngör, H.; J. Hazard. Mater. 2008, 153, 462.

3. Keramati, N.; Moheb, A.; Ehsani, M. R.; Desalination 2010, 259, 97.

4. Duran, Y.; Xiang, Y.; Xia, D.; Fuel Process. Technol. 2004, 86, 237.

5. Pacheco, M. E.; Salim, V. M. M.; Pinto, J. C.; Braz. J. Chem. Eng. 2009, 26,733 .

6. Pereira, K. S.; Schmidt, M. C. F.; Afonso, J. C.; Braz. J. Chem. Eng. 2010, 27, 591 . 
7. Ko, T. H.; Chu, H.; Lin, H. P.; Peng, C. H.; J. Hazard. Mater. 2006, 136, 776.

8. Afonso, J. C.; Pereira, K. S.; Quim. Nova 2010, 33, 957.

9. Krishnakumar, B.; Majumdar, S.; Manilal, V. B.; Haridas, A.; Water Res. 2005, 39, 639.

10. Botalova, O.; Schwarzbauer, J.; Frauenhrath, T.; Dsikowitzky, L.; Water Res. 2009, 43, 3797.

11. Park, J. J.; Byun, I. M.; Park, S. R.; Lee, J. H.; Park, S. H.; Park, T. J.; Lee, T. H.; J. Ind. Eng. Chem. 2009, 15, 316.

12. Sheu, S. H.; Weng, H. S.; Water Res. 2001, 25, 2017.

13. Graaf, M.; Bijmans, M. F. M.; Abbas, B.; Euverink, G. J. W.; Muyzer, G.; Janssesn, A. J. H.; Bioresour. Technol. 2011, 102, 7257.

14. Lurie, J.; Handbook of Analytical Chemistry, Mir: Moscow, 1978, chap. 3,6 and 10 .

15. The US EPA; Hazardous Waste Management System, Federal Register 1995, 60, 57747.

16. Henshaw, P. F.; Zhu, W.; Water Res. 2001, 35, 3605.

17. Debellefontaine, H.; Foussard, J. N.; Waste Manage. 2000, 20, 15.

18. Sipma, J.; Svitelskaya, A.; Mark, B.; Pol, L. W. H.; Lettinga, G.; Buisman, C. N. J.; Janssen, A. J. H.; Water Res. 2004, 38, 4331.

19. Buisman, C. N. J.; Uspeert, P.; Janssen, A.; Lettinga, G.; Water Res. 1990, $24,667$.
20. Janssen, A. J. H.; Lettinga, G.; Keizer, A.; Colloids Surf., A 1999, 151, 389.

21. Li, W.; Zhao, Q. L.; Liu, H.; J. Hazard. Mater. 2009, 162, 848.

22. Poulton, S. W.; Krom, M. D.; Rijn, J. V.; Raiswell, R.; Water Res. 2002. 36,825 .

23. Ahmad, N.; Maitra, S.; Dutta, B. K.; Ahmad, F.; J. Environ. Sci. 2009 , 21,1735 .

24. Lohwacharin, J.; Annachhatre, A. P.; Bioresour. Technol. 2010, 101, 2114

25. Feigl, F.; Spot Tests in Inorganic Analysis, Elsevier: Amsterdam, 1958, chap. 3.

26. APHA; Standard Methods for Examination of Water and Wastewater (APHA, AWWA), 21 $1^{\text {st }}$ ed., WPCF: New York, 2005.

27. Skoog, D. A.; Holler, F. J.; Nieman, T. A.; Principles of Instrumental Analysis, $5^{\text {th }}$ ed., Brooks Cole: New York, 1997, chap. 23.

28. National Brazilian Environmental Council - CONAMA; Directory $n$. 357, March 17, 2005.

29. Centi, G.; Prerathoner, S.; Catal. Today 1999, 53, 11; Hancock, F. E.; Catal. Today 1999, 53, 3.

30. Chanda, M.; Rempel, G. L.; React. Polym. 1995, 24, 203.

31. Sun, A.; Xiong, Z.; Xu, Y.; J. Mol. Catal. A 2006, 259, 1. 